\title{
AN INNOVATIVE LOW-COST AUTOMATIC PROTOTYPE FOR FRUITS AND VEGETABLES WEIGHT BASIS PACKAGING
}

\author{
Said Elshahat Abdallah* and Wael Mohamed Elmessery*
}

ABSTRACT

Nowadays most packaging machines manufacturers implement highly automated sophisticated components to be very costly. Moreover the economic circumferences and agricultural industry revolution in Egypt impose to find local technical solutions for all industrial production obstacles. The approach towards low cost automatic packaging prototype is depending on using simple pneumatic, mechanical, electrical and electronic devices in prototype manufacturing with high productivity concerns. These synergistic combinations of those engineering fields lead to the science of mechatronics. Open sources hardware provides the suitable environment for creation without additional costs. Three innovative embedded systems were designed and virtually simulated using software package Proteus Design Suite 8. The first one is for weighing process by an infrared (transmitter and receiver) and load cell sensors for information gathering to an open source microcontroller (ArduinoUno). Pneumatic pistons and DC motor were used as control system actuators. The DC motor was used to rotate the conveyor belt with different speeds controlled by the other two designs of embedded control systems, close loop system (phase locked loop technique integrated with pulse width modulation technique) and open loop system (pulse width modulation technique) were analyzed and compared using an oscilloscope for frequency graphing. The conveyor belt velocity was determined based on the information about product weight and the total weight required for packaging. The performance of each unit of the packaging prototype was analyzed. The experimental result of the packaging prototype was capable of fully automate three different types of fruits and vegetables which are lemon (Citrus aurantifolio), tomato Peto 86 (Lycopersicon escalentum-Mill) and ripe plum (Prunes salicina).

* Associate Professor of Agricultural Process Engineering, Agricultural Engineering Department, Faculty of Agriculture, Kafrelsheikh University 
Their physical properties; major, intermediate and minor dimensions are 44.8, 42 and 40.17mm, 75.19, 52.6 and 47.6mm and 49.98, 47.533, $42.06 \mathrm{~mm}$, respectively. Geometric diameters are 42.29, 57.35 and $46.4 \mathrm{~mm}$, respectively. The average sphericity index is 94.4, 76.3 and $92.8 \%$, respectively. Lemon and plum are tending to roll rather than sliding and show high compact arrangement inside the packaging material. Angle of repose of two different types of conveyor belts were tested with the fruits, the highest coefficient of friction is for nodded belt. Under open loop control the rotational speed of the DC geared motor was decreased in the range of 33 to $40 \%$ under full load condition; whereas the close loop control system remains the rotational speed constant, but consumes more electrical power of 50 to 55\%. The innovative embedded system of close loop control of the DC geared driver motor aids the weighing unit to obtain higher pack weight precision of the tomatoes, plum and lemon due to its higher regularity of conveyor belt velocity to fill the packs with product until one kilogram is achieved. These embedded systems have whole cost of 761.05LE, in comparison with other control systems of 5000 to 30000LE doing the same control work of automation. Further investigations will complete this work to apply this innovative embedded control system at fruits and vegetables packaging plants.

KEYWORDS: mechatronics, open source systems, embedded control systems, phase locked loop, pulse width modulation technique

\section{INTRODUCTION}

$\mathrm{F}$ lood process engineering automation becomes a universal trend; packaging process is one of the most agricultural industrial applications. Packaging technology is the using of conveyor belts for products enclosing into containers for transport, storage, sale and final consume. Sometimes packaging requires specific characteristics for optimum marketing depending on size, weight and other quality parameters. Packaging has many aspects of gains are: marketing and distribution, taste conservation, dust, moisture, microorganism protection and shelf-life extension (Mahalik, 2009). Automation technology aids to 
drive down the processed food costs versus whole food product. There are a lot of investigations in literature about food packaging industry such as equipment utilities evolution and optimization, waste reduction, improvements of control methods and automation (Kapoor et al., 2006). Despite there is a large variety of design methods of packaging machines for a specific subset, but there is no general accepted routine for designing a packaging plants (Fey, 2000). Processing plants productivity depends mainly on control scheme, instrumentation and automation, smartness degree of sensors and machines and mechanics sophistications as robotics, modern plants usually control all machine duties by Programmable Logic Controllers (PLCs) (Henery, 2012; Lingappa $\boldsymbol{e t}$ al., 2014 and Algitta et al., 2015). Personal Computers (PCs) or PLCs systems are considered nowadays to be redundant because they require more maintenance and expertise due to their incompatibility in host platform; they have limited interoperability in addition to being very costly (Mahalik, 2014). PLCs are built-in devices and did not have the ability to add or remove modules or kits according to operating updates in plant and cost much for any modifications and reuse, but on the other hand the open source Arduino microcontrollers has the potential solutions for the problems demonstrated above with reasonable price (Evans, 2011). Open source microcontrollers (Arduino series) running on free software package Arduino $\mathrm{C}$ enables the creation of potential scientific research tool at low costs (Durfee, 2011). Nowadays it is less expensive to manufacture and design agricultural engineering units than to import them. Scientific equipment designs by open source microcontrollers also increases the production of powerful experimental instrumentation. So the present investigation is devoted to design a control system by open source hardware for packaging automation.

The main objective of the current research is designing a suitable low-cost embedded control system for packaging lines (applied on packaging prototype) and analyzing the performance of each unit of the prototype as follows:

1. Weighing unit: package weighing precision affected by the following engineering parameters (a) belt rotational speed controlled by two different designs of control systems of the 
driver motor (b) physical properties of the fruits and vegetables under investigation.

2. Sealing unit and package welding perfection affected by Ohmic coil temperature and pressing force.

\section{MATERIALS AND METHODS}

\section{Manufactured weight basis packaging prototype}

An automatic weight basis packaging prototype manufacturing is depending on three engineering approaches as electronic, mechanical and pneumatic.

\section{Electronic approach}

\section{Innovative low-cost control system}

The whole control system is consisting of three innovative embedded systems. The three embedded systems were designed and functionally investigated on the weight basis packaging prototype. These embedded systems can be used as same for larger packaging plants with same costs of construction. The low-cost concept is depending on using open sources (software is free and available on webs and the hardware is had a reasonable price) instead of other expensive sources as PLC and multifunction systems. The Embedded system is a computer system doing a definite function inside a greater mechanical or electrical system. Each one of these embedded systems (Weighing and pneumatic conveyor control system and two control systems of driver motor speed) was designed on virtual software package of Proteus Design Suite 8, Figure1, which provides a powerful working environment to develop the Printed Circuit Board (PCB) of Pulse Width Modulation (PWM), Digital Phase Locked Loop (DPLL) circuits and simulates all functions of these circuits. Other advantage of this virtual program of Proteus its ability to simulate the written instructions program of the microcontroller Arduino-Uno and determine the program faults during control functions performing.

\section{a. The first embedded system for weighing unit control}

The weight information can be identified by a load cell capacity of $5 \mathrm{~kg}$ with precision of $0.05 \%$ and rated output of $1.0 \pm 0.15 \mathrm{mV}$. Load cell send an analog signal of voltage to an Arduino-Uno board proportional to product weight. The Arduino-Uno microcontroller was programmed to 
deliver a specific weight of product for each packaging plate. Load cell connection concerns to the board of Arduino need an interface module HX711 for further proper data process is shown in Figure 2. HX711 is a module used in many industrial controls for output signal conditioning from all bridge sensor applications. HX711 module can amplify the acquired analog signal (voltage signal) by 10 to $12 \mathrm{mV}$ and convert it to a digital signal with high precision of 24bit.

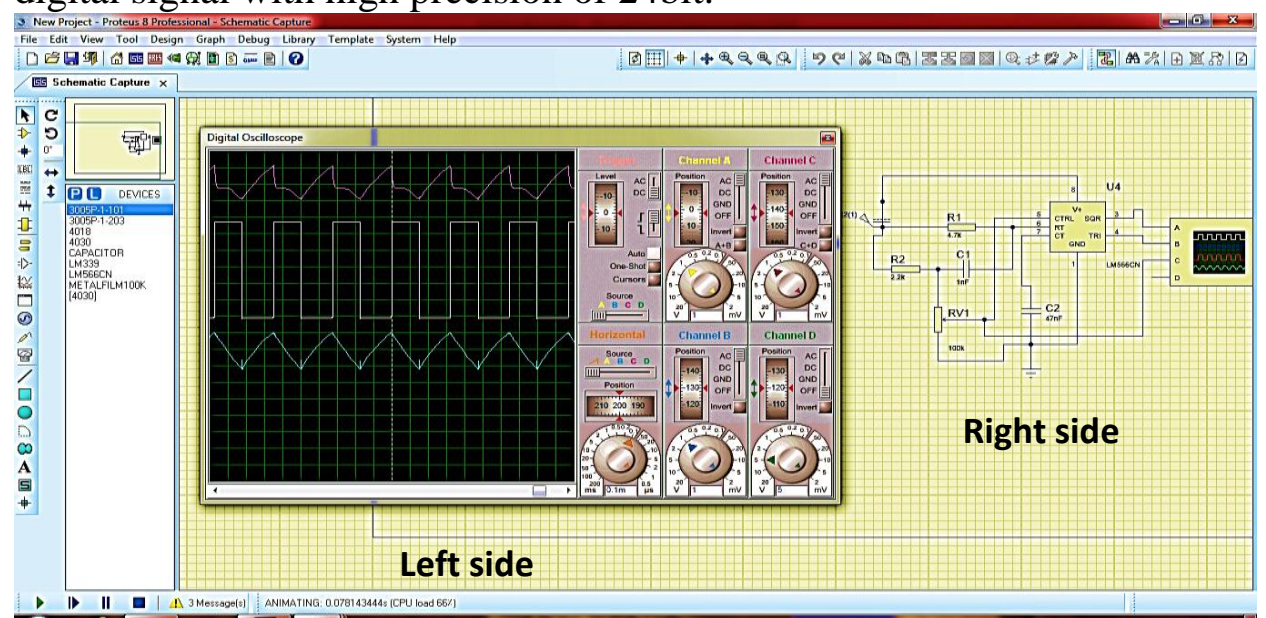

Figure 1. The Virtual analysis of the new designed electronic circuits by the software package of Proteus Design Suite 8. Right side is the circuit under investigation and the left side is the virtual Oscilloscope for signal output analysis

\section{Arduino-Uno board}

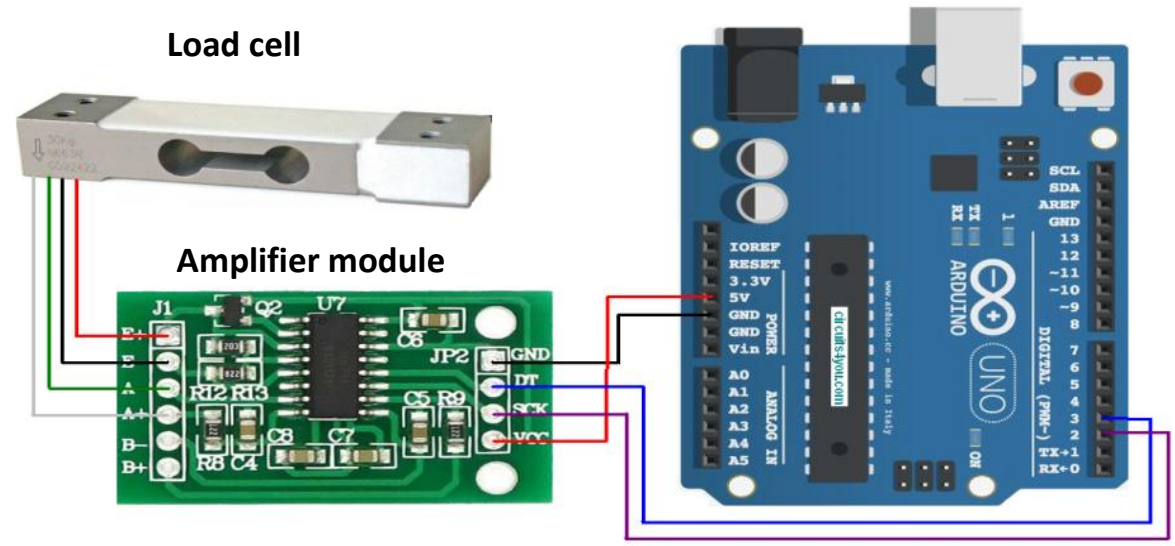

Figure 2. Load cell connection diagram to HX711 amplifier module interface and microcontroller Arduino-Uno board 


\section{Initialization function}

Packaging process was begun by an Infrared sensor implemented above the metal plate connected to the load cell by two screw bolts. As packaging plate cut the infrared beam the microcontroller (Arduino) begins to acquire weight information until the specific weight is achieved (Figure 3), this signal synchronization was regulated by U1 (4043 Tristate (Quad R/S Latch)), U1 (4043) sends a signal to the solid state switch MOSFET through its gate to permit the power to supply to the second circuit of pulse width modulation, Figure 3. The microcontroller actuates the pneumatic piston to push the packaging plate to the sealing unit. The wavelength of infrared sensor is 680nanometer with voltage of $1 \mathrm{mV}$ and the room light does not affect the infrared receiver.

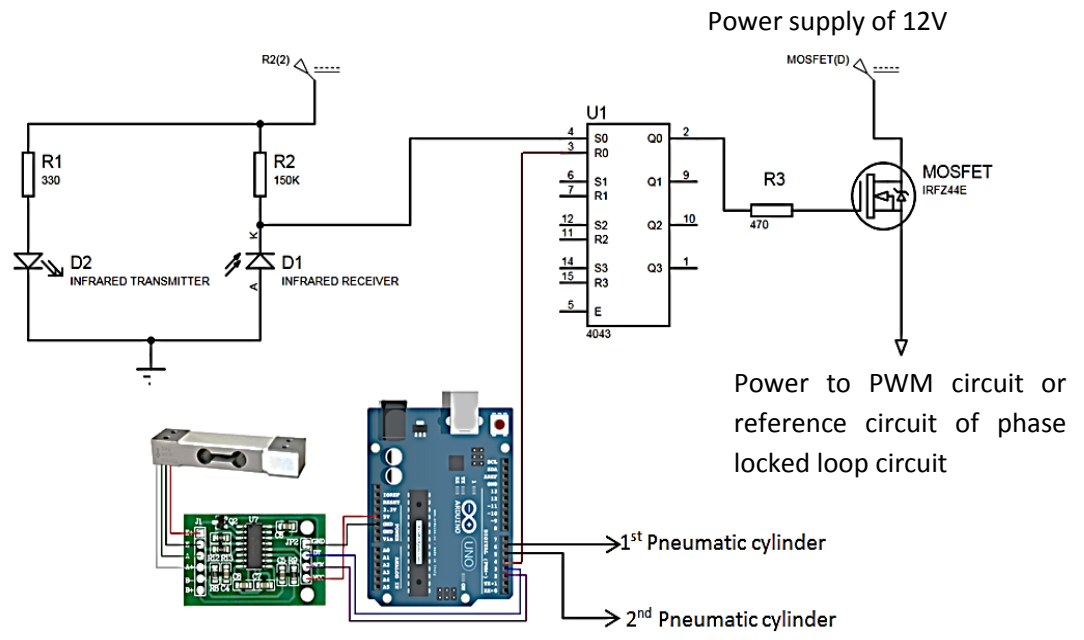

Figure 3. Infrared and Ohmic sealing embedded system diagram

\section{b. Second and third embedded system for conveyor belt velocity control}

\section{i. Second embedded system for open loop control using PWM technique}

Pulse Width Modulation (PWM) technique was used to control the rotational speed of DC motor of the conveyor belts that transport the product under study (fruit or vegetable) from feeding hopper to weighing unit, for further packaging into plates. PWM technique is used in this manufacturing to reduce the transition losses and increases the efficiency. PWM is an infinite series of rapid square pulses. Pulse train and amplitude represent two items of time and switching states of "ON" or 
"OFF" respectively. Timing is the predominant parameter in PWM to regularly turn on or off its power to vary the amount of output power. Duty cycle is the time percentage of turned on pulse throughout each pulse period. Output power can be varied by varying the duty cycle. Two PWM circuits were virtually designed and experimented by Proteus design suite 8 and constructed for open loop control system and the other for close loop control system, Figures 4. Power supply (ATX) which found in PCs was used to execute all circuits that need voltage levels of $12 \mathrm{~V}$ and $5 \mathrm{~V}$.

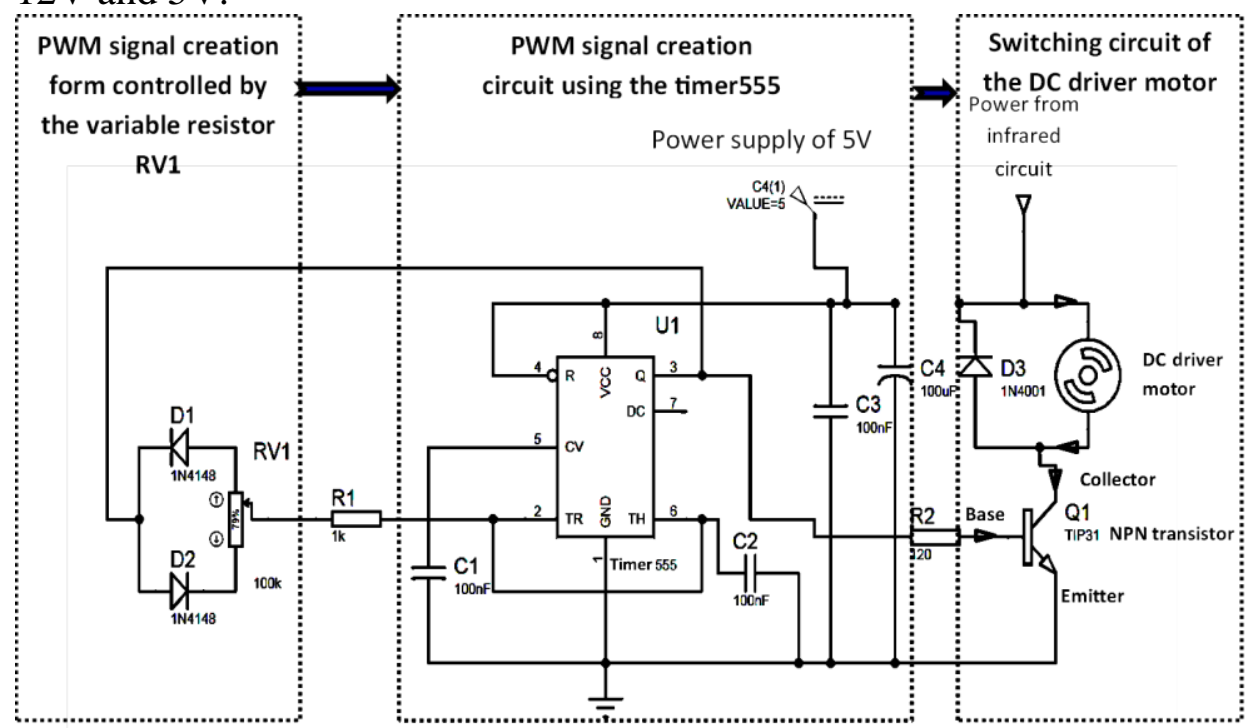

Figure 4. Second embedded system for pulse width modulation based on oscillator timer 555, RV1 is the variable resistance used to adjust the pulse duty cycle to vary the Belt Conveyor Motor (BCM) rotational speed

First of all the variable resistor of $100 \mathrm{k} \Omega$ was adjusted at a certain position for example $50 \%$ of its full scale, the PWM creates a signal of $50 \%$ of its full power (50\% ON and 50\% OFF state). According to the electrical pulses sent by the PWM creation circuit through the resistor R2 of $120 \Omega$ to the base of the Negative Positive Negative (NPN) transistor if the signal is $\mathrm{ON}$, the transistor closes the circuit to turn on the DC motor and vice versa if the signal is in OFF state, the transistor open the circuit, Figure 4. These instantaneous pulses regulate the rotational speed of the DC motor. 


\section{ii. Third embedded system for close loop control using DPLL}

For large scale application, the uniformity of driven motor rotational speed should be considered, which varied usually according the applied load on the belt, modern sensor less technology (Digital Phase Locked Loop). This DPLL is feedback loop which is consisting of phase detector (QUAD XOR Gate 4030), low pass filter circuit, switching driver circuit of MOSFET, Figure 5, for power application of DC motor control and the rotary encoder deliver the feedback signal with a specific pulse train. Phase detector compares between the PWM signal generated by PWM circuit, Figure 6, used as a reference signal and the feedback signal provided by the rotary encoder. The pulse train of PWM signal (reference signal) was controlled by a variable resistor to investigate the optimum conveyor belt velocity for each agricultural product under study.

signal, $\mathrm{F}_{\mathrm{B}}$

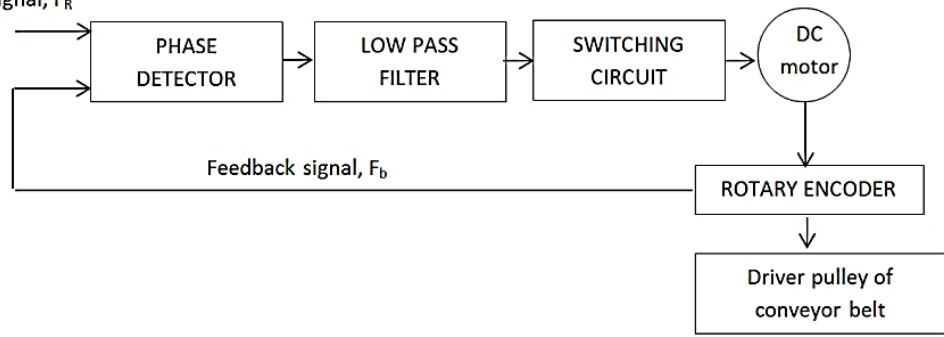

Figure 5. Block diagram of the third embedded system for belt driver motor rotational speed-control system with phase locked loop technique

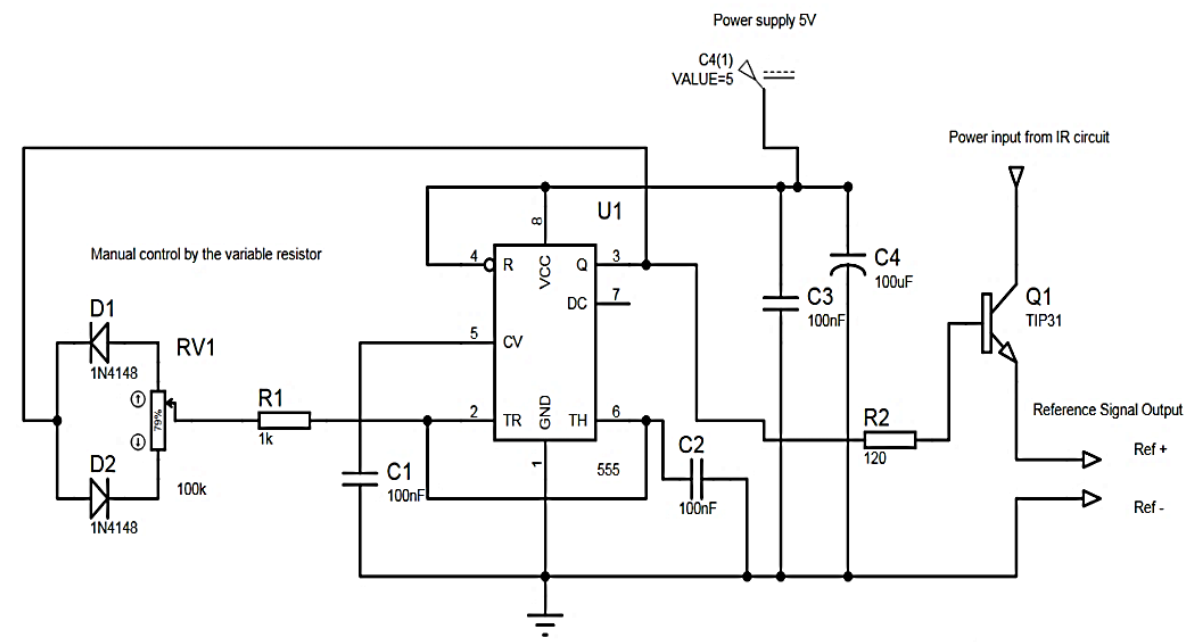

Figure 6. Reference signal circuit generated by pulse width modulation circuit and the pulse train is controlled by a variable resistor 


\section{Mechanical approach}

i. Feeding hopper

As shown in Figure 7, an inclined four faces feeding hopper was fabricated from blue corrugated transparent solid fiber material. The hopper dimensions were $250 \mathrm{~mm}$ length, $250 \mathrm{~mm}$ width and $300 \mathrm{~mm}$ height. The hopper wall has an inclination angle of 60 degrees, but at hopper base the outlet has an angle value more than the angle of repose of 38 degrees of most of fruits and vegetables that has spherical shapes to maintain the flow of products at a regular rate.

ii. Belt conveyor system

The belt conveyor system consists of $12 \mathrm{~V} \mathrm{DC}, 0.014 \mathrm{hp} \mathrm{Entstort} \mathrm{gear}$ motor of 40-60rpm (reduction ratio of 170:1) which drives a pulley of 2 inches (about $5 \mathrm{~cm}$ ) in diameter. The loop of flexible belt from rubber has a length of $58 \mathrm{~cm}$ and width of $30 \mathrm{~cm}$ has a nodded surface that moves spherical shapes easily, the maximum conveyor belt velocity achieved was of $7 \mathrm{~cm} / \mathrm{s}$.

\section{Pneumatic approach}

The pneumatic conveyor system is used in two locations:

i. To push horizontally the plate on the weighing unit after filling with a predetermined weight to Ohmic sealing unit.

ii. To shove the Ohmic heating coil on the plate for welding the plastic sheet.

The pneumatic conveyor system consists of the following components as:

i. Step down transformer of $220 \mathrm{~V}$ to $12 \mathrm{~V}$ which is sufficient in providing the required power of $12 \mathrm{~V}$ and $3 \mathrm{~A}$ to the air brush compressor.

ii. Air brush compressor with outlet flow rate of 50 liters per minute and air pressure of 5 to $10 \mathrm{bar}$ is connected to an air tank with a capacity of 15 liters and pressure class of $10 \mathrm{bar}$.

iii. Check and safety valves for air delivered non-return by the air brush compressor and air tank high air pressure eluding, respectively.

iv. Supplied air pressure regulator SQUARE D (made in Italy) keeps the air pressure in the tank constant by turning the air brush compressor 'ON' or 'OFF' to be at the range between 4.5 and 5.5bar which is more suitable for system operations. 
v. Delivered air pressure regulator which controls the air discharging pressure from the air tank to the pneumatic five ways solenoid valve.

vi. Pneumatic five ways solenoid valve

Two solenoid valves of five ways were used for the two pneumatic cylinders for forward and backward pushing operations controlled by the Arduino board.

vii. Pneumatic air exhaust silencers

Two exhaust silencers were used for each pneumatic air solenoid valve to regulate the pushing force of the two pneumatic cylinders

viii. Pneumatic air cylinder

Two stainless steel adjustable stroke type pneumatic air cylinders were used, Table1; the first one is exploited to transfer the packaging plate from the weighing unit to be centered under the Ohmic heating coil (first location) which thrust by the other vertical pneumatic air cylinder (second location).

Table 1. Pneumatic air cylinders specifications

\begin{tabular}{|l|c|c|}
\hline \multirow{2}{*}{ Items } & \multicolumn{2}{|c|}{ Pneumatic air cylinder locations } \\
\cline { 2 - 3 } & At first location & At second location \\
\hline Piston diameter, $\mathrm{cm}$ & 1.4 & 2.5 \\
\hline Piston stroke, $\mathrm{cm}$ & 20 & 10 \\
\hline Piston rod diameter, $\mathrm{cm}$ & 0.6 & 0.6 \\
\hline
\end{tabular}

Pneumatic air cylinder pushing force was calculated as $\mathrm{F}=\mathrm{A} \times \mathrm{P} \times \mathrm{FF}$ Where, $\mathrm{F}$ is the cylinder pushing force, $\mathrm{kg}_{\mathrm{f}}$; $\mathrm{A}$ is the piston surface area, $\mathrm{cm}^{2} ; \mathrm{P}$ is the air pressure, 3.5bar and FF is the friction factor, 0.9.

All components are working in sequence and synchronic operations. The whole prototype implements different pneumatic, mechanical, electrical and electronic parts in manufacturing. The innovative packaging prototype was constructed and installed at Agricultural Engineering Department, Faculty of Agriculture, Kafrelsheikh University, Egypt. The experimental treatments of packaging process were run during spring and summer of 2017.

\section{Experimental Procedures}

Series arrangements among control circuits and mechanical parts were correlated for proper synchronization to achieve optimum and high precise packaging process. 


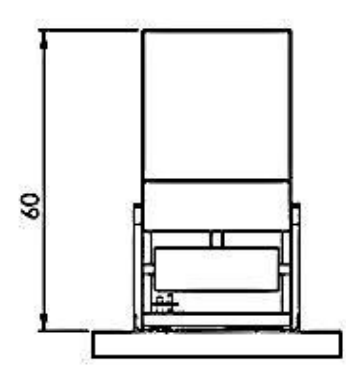

Elevation view

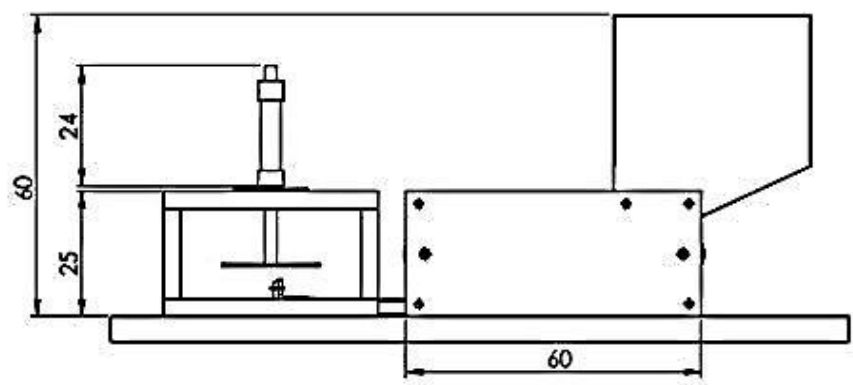

Side view

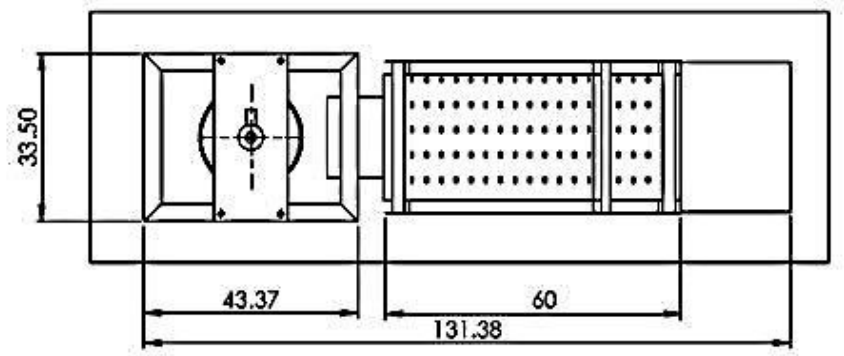

Dimensions in cm

Plan view

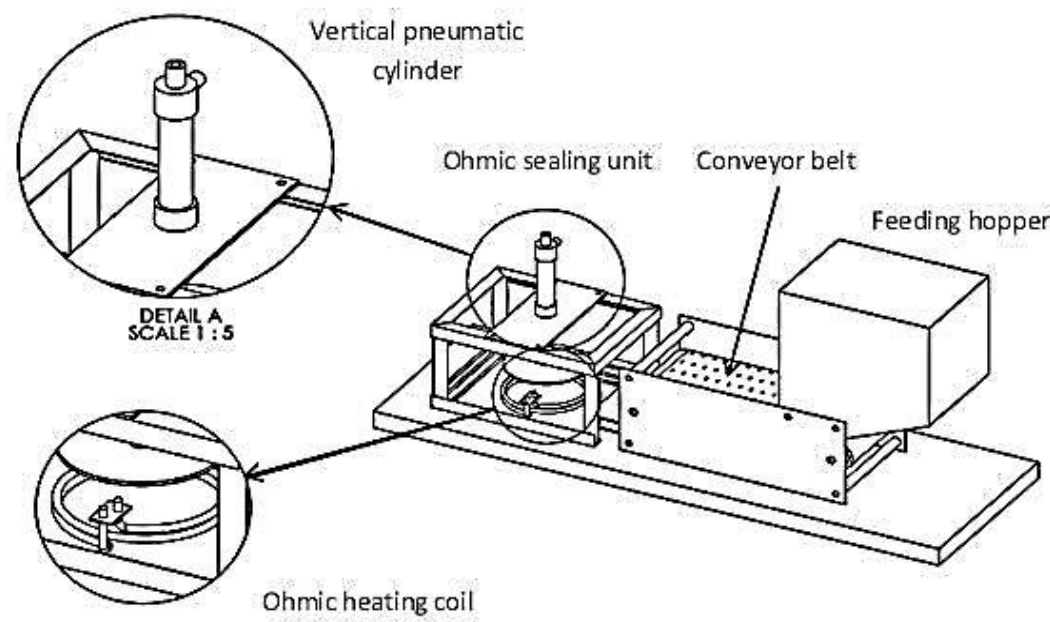

Figure 7. Schematic drawings of the mechanical part of the packaging prototype

As feeding hopper filled with the product under study (two species of fruits and vegetables) the conveyor belt starts to rotate by an electrical DC motor carrying the product to weighing unit, that receives the products in 
a small packaging plate until one kilogram is achieved, after that the packaging plate is pushed by a horizontal pneumatic piston located beneath the conveyor belt to Ohmic sealing unit. Ohmic heating coil is pushed down by a vertical pneumatic piston for a certain time under study for welding of the covering plastic sheet.

\section{Packaging prototype performance analysis}

The performance of each unit of the packaging prototype was experimented under the new embedded control systems as follow:

\section{a. Weighing unit precision}

After packaging process, fifty packs of each experimental trial were weighed by digital balance of precision of $0.01 \mathrm{~g}$. Weighing data obtained were statistically analyzed (mean, standard deviation and coefficient of variation) by Microsoft Excel 2010 and create graphically their normal distribution curves.

\section{i. The effect of control system type}

Two types of control systems were designed and investigated on the packaging prototype to infer what type of control is proper for conveyor belt movement. Close loop control system is aimed to keep the rotational speed of the belt constant under different load conditions. Open loop control system acts completely on the input of applied electrical power and the output (conveyor belt rotational speed) has no effect on the control action. So the driver motor speed can vary according to the load applied to the belt under the same application of electrical power.

The effect of conveyor belt rotational speed consistency on filling uniformity of the pack with fruits or vegetables was considered to be under investigation. Driver motor operated with close loop system (phase locked loop technique) and open loop system were analyzed and compared using an oscilloscope for frequency graphing.

ii. The effect of physical properties of fruits and vegetables on weighing precision

The relationship between apparent volume of fruits and vegetables and weighing precision was considered in this study for due to the embedded control system was programmed for one kilogram weighing for each pack. If the pack is less than one kilogram by few grams, the 
control action is in hibernate state until one or two fruits are added for weighing complementary depending on their volumes.

\section{Sealing unit perfection}

\section{i. The effect of Ohmic coil temperature}

Different levels of Ohmic coil temperatures beginning from $40^{\circ} \mathrm{C}$ with an increment of $1^{\circ} \mathrm{C}$ until to $70^{\circ} \mathrm{C}$. The optimum sealing temperature will be determined according to welding and fusion state which is visually evaluated.

\section{ii. The effect of Ohmic coil compression}

Different levels of pressures were applied by vertical pneumatic cylinder on Ohmic coil to seal the package by fusing (welding action) starting from 2 bar with a raise of 1 bar until to 8bar. Ohmic coil compression and temperature are the two major engineering parameters affecting welding efficiency.

\section{Physical properties of fruits and vegetables}

Fresh samples of plum were collected for packaging developing and experimentation. The physical properties were determined by the following formulas, (Mohsenin, 1978 and Razavi and Parvar, 2007):

- To determine the shape indices, the included parameters are

a. major, minor and intermediate diameters

b. Sphericity index and aspect ratio

$$
S_{i}=\frac{(m n i)^{1 / 3}}{m} \times 100
$$

Where; $m=$ major, $n=$ minor and $i=$ intermediate

For aspect ratio, $A_{r}$

Geometric diameter, $D_{g}$

$$
A_{r}=\frac{n}{m} \times 100
$$

$$
D_{g}=(m n i)^{1 / 3}
$$

Arithmetic diameter, $D_{a}$

c. True density, $\rho_{t}$

$$
D_{a}=\frac{(m+n+i)}{3}
$$


Twenty randomly samples of fruits were weighed $\left(M_{\text {air }}\right)$ and immersed into graduated bottle of water of $1000 \mathrm{~cm}^{3}$. The weight of displaced water gives the fruits weight in water $\left(M_{\text {water }}\right)$. True volume $\left(V_{t}\right)$ can be calculated as follow:

$$
V_{t}=\frac{M_{\text {air }}-M_{\text {water }}}{\rho_{\text {water }}}
$$

Where, $\rho_{\text {water }}$ is water density, then the true density can be obtained by

$$
\rho_{t}=\frac{M_{\text {air }}}{V_{t}}
$$

Apparent volume can be calculated by following formula

$$
V_{a}=\frac{4 \pi}{3} m n i
$$

d. Bulk density, $\rho_{b}$

Weight of a filled container with fruits was measured and subtracted

from the weight of empty container only to give the bulk mass $\left(M_{b}\right)$.

The container volume gives $\left(V_{b}\right)$.

$$
\rho_{b}=\frac{M_{b}}{V_{b}}
$$

The porosity of bulk fruits $(P)$ can be calculated by true and bulk

density using the following relationship (Mohsenin, 1978):

$$
\% P=\left(1-\frac{\rho_{b}}{\rho_{t}}\right) \times 100
$$

Coefficient of friction was determined for the material of belt conveyor. High density polyethylene box without sides of bottom and top has dimensions of $0.2 \mathrm{~m}$ length and width and $0.05 \mathrm{~m}$ height was put on an adaptable tilting plate. The box filled with the fruit samples and the bottom edge was raised somewhat of $(3-6 \mathrm{~mm})$ to be away from the belt surface. The belt surface was inclined gradually by a screw element until the box with the fruit samples begin to slide down above the surface, the angle of tilt $(\alpha)$ was recorded to calculate the coefficient of friction $(\mu=\tan \alpha)$.

\section{RESULTS AND DISCUSSION}

\section{Physical properties of plum, lemon and tomatoes}

Most of fruits and vegetables have a spherical geometric shape. Physical properties of two types of fruits (plum and lemon) and one of vegetable 
(tomato) were studied in this experimental run of the new innovative packaging prototype. The main purpose of the developed packaging prototype is to pack the same weight (One kilogram) of the agricultural product for marketing optimization. Fruit volume and surface uniformity affect packaging efficiency.

\section{Geometric diameter and morphological dimensions}

The average major, intermediate and minor for ripe plum (Prunes salicina), lemon (Citrus aurantifolio) and tomato Peto 86 (Lycopersicon escalentum-Mill) were used for conveyor belt adaptation, Figure 8. Lemon, tomato and plum dimensions (major, intermediate and minor) were 44.8, 42 and 40.17mm, 75.19, 52.6 and 47.6mm and 49.98, 47.533, $42.06 \mathrm{~mm}$, respectively. Geometric diameters calculated from the measured dimensions are 42.29, 57.35 and $46.4 \mathrm{~mm}$ for lemon, tomato and plum, respectively. The average sphericity index $S_{i}$ and aspect ratio $A_{r}$ of lemon, tomato and plum are $(94.4,89.7),(76.3,63.3)$ and $(92.8,84.1)$, $\left(S_{i} \%, A_{r} \%\right)$, respectively, Figure 9.

High sphericity means that the fruit tending to the sphere shape and the fruit has more ability to roll than to slide on a flat surface, such as lemon and plum have higher sphericity than tomatoes. For transporting process from the hopper to weighing unit, spherical shapes (lemon and plum) are perfect in rolling on the inclined plate beneath of the fruit hopper on the contrariwise tomatoes are not rolling good. As the fruits become on the conveyor belt, it should be stable to be transported. So the belt that has the highest coefficient of friction (angle of repose) with fruits is favored. As indicated at Table 2, the nodded belt is preferred. High sphericity is an indication of low porosity which gives a high compact arrangement inside the package which requires low volume of packaging material.

Table 2. Fruit properties

\begin{tabular}{|c|c|c|c|c|c|}
\hline \multirow[t]{2}{*}{ Fruit } & \multicolumn{2}{|c|}{ Angle of repose } & \multirow{2}{*}{$\begin{array}{c}\text { True } \\
\text { density, } \\
\mathrm{kg} / \mathrm{m}^{3}\end{array}$} & \multirow{2}{*}{$\begin{array}{c}\text { Bulk } \\
\text { density, } \\
\mathrm{kg} / \mathrm{m}^{3}\end{array}$} & \multirow[b]{2}{*}{$\begin{array}{l}\text { Porosity, } \\
\quad \%\end{array}$} \\
\hline & Flat belt & $\begin{array}{c}\text { Nodded } \\
\text { belt }\end{array}$ & & & \\
\hline $\begin{array}{l}\text { Lemon (Citrus } \\
\text { aurantifolio) }\end{array}$ & $6 \pm 0.48^{\circ}$ & $12 \pm 0.72^{\circ}$ & $925 \pm 12$ & $572 \pm 20$ & 57 \\
\hline Plum (Prunes salicina) & $6 \pm 0.52^{\circ}$ & $13 \pm 0.94^{\circ}$ & $803 \pm 20$ & $400 \pm 50$ & 50 \\
\hline $\begin{array}{l}\text { Tomatoes Peto } 86 \\
\text { (Lycopersicon } \\
\text { escalentum-Mill) }\end{array}$ & $7 \pm 0.92^{\circ}$ & $18 \pm 2.15^{\circ}$ & $900 \pm 23$ & $422 \pm 22$ & 49 \\
\hline
\end{tabular}




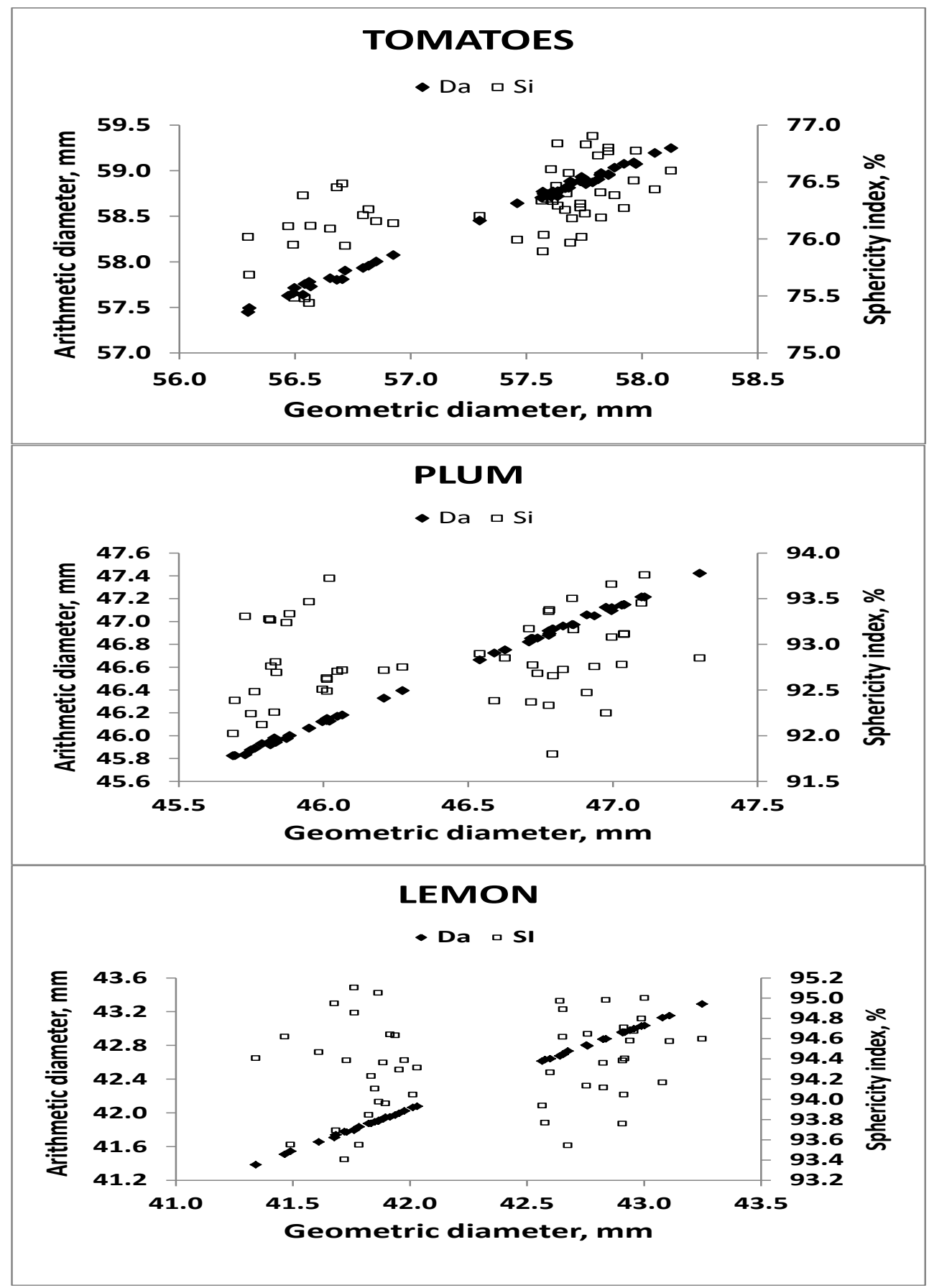

Figure 9. Sphericity index $\left(S_{i}\right)$ range for different geometric $\left(D_{g}\right)$ and arithmetic diameters $\left(D_{a}\right)$ of the fruits. 


\section{Driver motor operated with close loop control system (phase locked loop technique) performance analysis}

Figure 10 shows the signal form of the predetermined reference signal generated by PWM circuit, feedback signal obtained by the rotary encoder which measures the rotational speed of the DC driver motor and finally the logic output of the phase comparator which controls the amount of electrical power applied to the DC driver motor. In close loop system (phase locked loop) the predetermined reference signal is acknowledged to be $100,75,50$ and $25 \%$ of the duty cycle. As shown at Figure 10A, the reference signal was $75 \%$ of the duty cycle. The reference signal was determined by a variable resistor in the PWM circuit that controls the pulse train of frequency (is proportional to motor speed) which gives the required rotational speed of the driver motor. Pulse width was measured by an oscilloscope to give the information about the optimum pulse train under different operating conditions. At initialization phase detector sends the reference signal to the switching circuit to operate the DC driver motor. Rotational speed was monitored by a rotary encoder. The programmable divide-by- $\mathrm{N}$ counter was used to condition the signal obtained from the rotary encoder and provide the feedback signal to the phase detector (comparator), Figure 10B. The comparator output provides a voltage proportional to the phase difference between the two feedback and reference signals. As seen from Figure 10C is a comparison result done by exclusive or logic gate (XOR logic gate) between the reference signal and feedback signal.

The output signal is tends to forte the applied electrical power by enhancing the duty cycle (pulsing time). Close loop system keep the rotational speed constant as indicated at Table 3. When DC driver motor is operated under different load conditions, the electrical current will increase to overcome the excess load until full loaded as consequent.

\section{Driver motor performance with open loop system}

Driver motor operated by open loop system is using pulse width modulation technique to regulate the rotational speed of the geared motor manually. Pulse train frequency for each level of electrical power applied to the motor was shown at Figure 11. It was observed from Table 4 that the motor speed decreases as load rises on the motor. 
Table 3. Driver motor rotational speed under close loop control

\begin{tabular}{|c|c|c|c|c|c|c|}
\hline \multirow{2}{*}{$\begin{array}{c}\text { Signal } \\
\text { Potential, \% }\end{array}$} & \multicolumn{2}{|c|}{$\begin{array}{c}\text { Number of pulses } \\
\text { per time, } \mu \mathrm{S}\end{array}$} & \multicolumn{2}{c|}{$\begin{array}{c}\text { DC geared motor } \\
\text { speed, rpm }\end{array}$} & \multicolumn{2}{c|}{$\begin{array}{c}\text { Electrical current, } \\
\text { Ampere }\end{array}$} \\
\cline { 2 - 7 } & ON & OFF & $\begin{array}{c}\text { With no } \\
\text { load }\end{array}$ & $\begin{array}{c}\text { Full } \\
\text { loaded }\end{array}$ & $\begin{array}{c}\text { With no } \\
\text { load }\end{array}$ & $\begin{array}{c}\text { Full } \\
\text { loaded }\end{array}$ \\
\hline 100 & 4 & 0 & 60 & 60 & 0.45 & 1.01 \\
\hline 75 & 3 & 1 & 45 & 45 & 0.32 & 0.48 \\
\hline 50 & 2 & 2 & 30 & 30 & 0.22 & 0.34 \\
\hline 25 & 1 & 3 & 15 & 15 & 0.15 & 0.3 \\
\hline
\end{tabular}
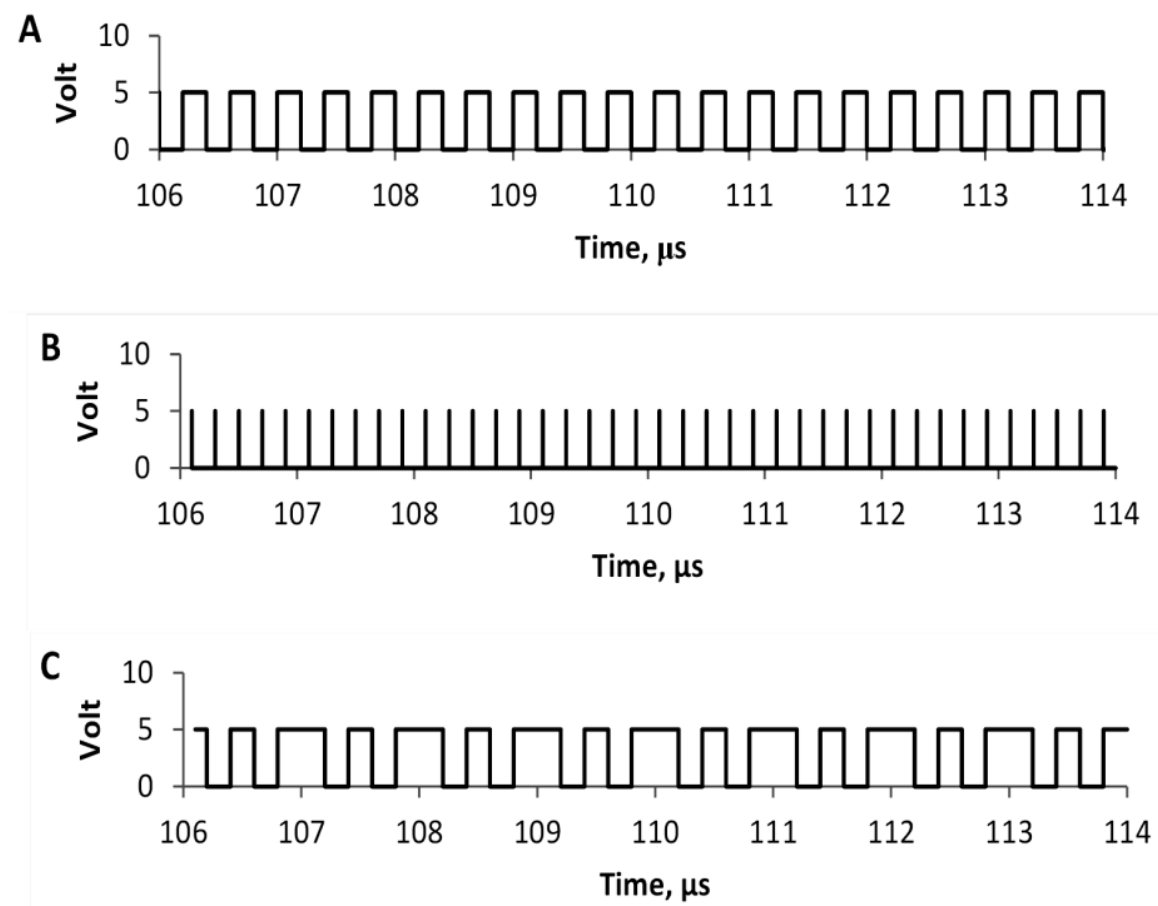

Figure 10. Oscillographic of electrical voltage analysis of reference signal (A) of PWM circuit, feedback signal of rotary encoder (B) and output logic signal (XOR) (C) under full loading condition

Table 4. Driver motor rotational speed under open loop control

\begin{tabular}{|c|c|c|c|c|}
\hline \multirow{2}{*}{$\begin{array}{c}\text { Signal } \\
\text { Potential, } \\
\%\end{array}$} & \multicolumn{2}{|c|}{$\begin{array}{c}\text { Number of pulses per } \\
\text { time, } \mu \text { s }\end{array}$} & \multicolumn{2}{c|}{$\begin{array}{c}\text { DC geared motor } \\
\text { speed, rpm }\end{array}$} \\
\cline { 2 - 5 } & ON & OFF & $\begin{array}{c}\text { With no } \\
\text { load }\end{array}$ & $\begin{array}{c}\text { Full } \\
\text { loaded }\end{array}$ \\
\hline 100 & 4 & 0 & 60 & 40 \\
\hline 75 & 3 & 1 & 45 & 30 \\
\hline 50 & 2 & 2 & 30 & 18 \\
\hline 25 & 1 & 3 & 15 & 9 \\
\hline
\end{tabular}




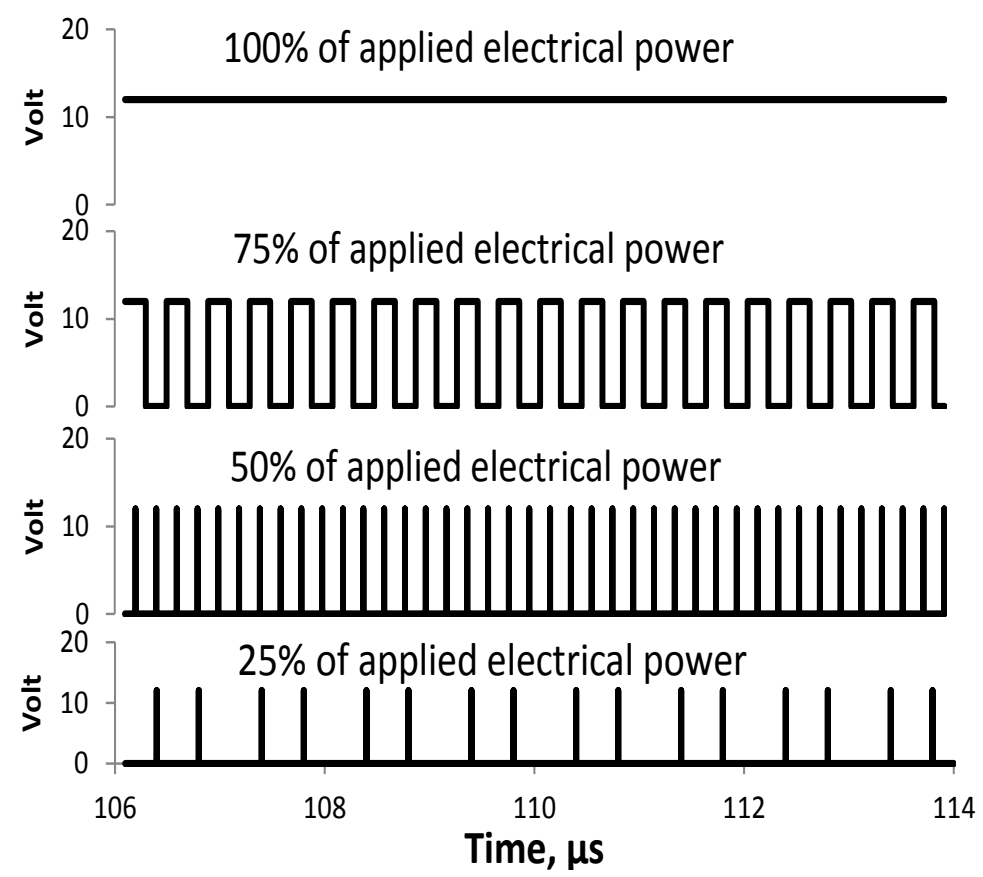

Figure 11. Driver motor controlled by PWM technique (open loop system)

\section{Fruit pushing force}

Pushing force by the conveyor belt, which applied to accelerate the fruits toward packaging plate to be weighed, was measured for each product. Lemon pushing force was significantly lower than the others at higher conveyor belt velocity due to its lower mass and nearly the same acceleration response to the applied pushing force, Figure 12. From the experimental physical observations, the optimum conveyor belt velocity was of $4 \mathrm{~cm} / \mathrm{s}$. Regression analysis for each fruit type was indicated at Table 5 to predict the effect of belt's velocity on fruit pushing force. General equation form are represented by Equation 10 .

\section{Sealing unit performance analysis}

The performance of packaging material sealing unit was analyzed to determine the optimum coil temperature for packaging material cutting. The optimum applied pressure by the vertical pneumatic cylinder was at 4 bar and coil temperature of $54^{\circ} \mathrm{C}$ for optimum welding time of $4.33 \mathrm{~s}$ due to the package after welding doesn't have any extended fuse in deep and there are no holes at outside, as shown at Figure 13. 


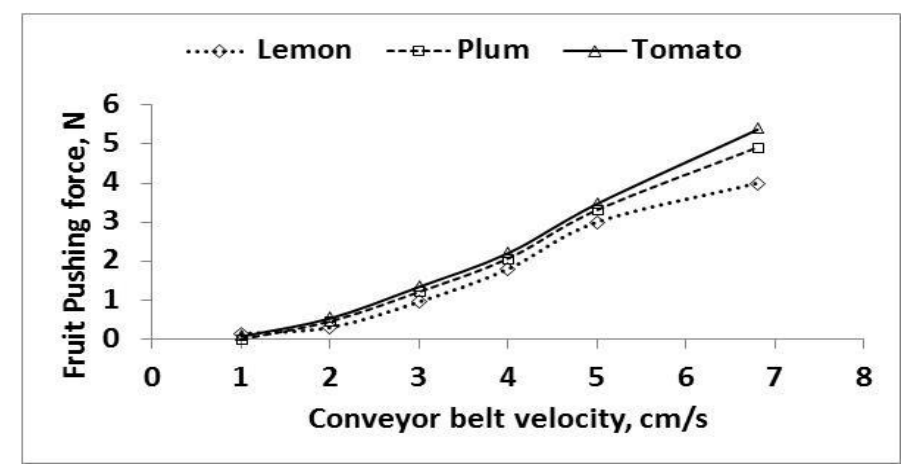

Figure 12. The relationship between fruit pushing force and conveyor belt velocity

$$
\mathrm{P}_{\mathrm{f}}=a v^{3}+b v^{2}+c v+d
$$

Eqn 10

Table 5. Pushing force regression analysis of different fruits

\begin{tabular}{|l|l|l|l|l|l|}
\hline Fruit type & $\mathrm{a}$ & $\mathrm{b}$ & $\mathrm{c}$ & $\mathrm{d}$ & $\mathrm{R}^{2}$ \\
\hline Tomato & -0.0175 & 0.2686 & 0.236 & 0.0626 & 0.999 \\
\hline Plum & -0.0231 & 0.317 & -0.3846 & 0.1065 & 0.999 \\
\hline Lemon & -0.0438 & 0.546 & -1.2258 & 0.8815 & 0.998 \\
\hline
\end{tabular}

Where (a), (b), (c) and (d) are the $1^{\text {st }}, 2^{\text {nd }}, 3^{\text {rd }}$ and $4^{\text {th }}$ multiple linear equation parameters, $P_{f}$ is the fruit pushing force, $N$ and $v$ is the conveyor belt velocity, $\mathrm{cm} / \mathrm{s}$


Figure 13. Effect of coil temperature and vertical pneumatic cylinder pressure on packaging material welding time. 


\section{Weighing unit performance analysis \\ The effect of control type}

As illustrated in the Figure 14, it can be inferred that the weighing unit performance is affected by conveyor belt rotational speed regularity. Close loop control system has the highest weighing precision for all fruits and vegetables due to its higher regularity of conveyor belt rotational speed. The conveyor belt rotational speed regulates the filling process of the agricultural products introduced to the packaging plate. The lowest coefficient of variation (C.O.V) obtained of 0.00242 of lemon packs with mean weight of $1007.88 \pm 2.71 \mathrm{~g}$ is due to their smallest weight of each fruit which aids the system to be more precise for package weighing than other agricultural products of tomatoes and plums.

\section{The effect of physical properties}

As shown above the morphological properties and conveyor belt movement affect proportionally on fruit arrangement inside the packaging plate and on consequences the weighing precision. Fruit apparent volume affects dramatically weighing operation. Tomatoes have the highest average apparent volume of $790 \pm 23.12 \mathrm{~cm}^{3}$ for that reason the tomatoes have the lowest weight precision of $1029.6 \pm 3.2 \mathrm{~g}$. However, lemon fruits have the smallest apparent volume of $316.5 \pm 11.96 \mathrm{~cm}^{3}$ and the most precise of weighing operation of $1007.38 \pm 3.55 \mathrm{~g}$.

\section{Package transmission by pneumatic conveyors}

The horizontal pneumatic cylinder pushing force affects sliding velocity of packaging plate from weighing unit to sealing unit, Figure 15. It was observed from the figure that the pushing force of $4 \mathrm{~N}$ is the optimum applied force to obtain sliding velocity of $5.1 \mathrm{~cm} / \mathrm{s}$ without any deformations of the packs.

\section{Economic contribution of the innovative control system}

The close and open loop control systems makes the packaging prototype has the flexibility advantage to be semi and full automated machine. Lowcost electronic components bought from RAM-Electronics and FutureElectronics companies, as indicated at Table 6 (RAM, 2018 and Future, 2018). 
TOMATOES



PLUM

\begin{tabular}{|c|c|c|}
\hline \multirow{2}{*}{ Item } & \multicolumn{2}{|c|}{ Plum } \\
\cline { 2 - 3 } & $\begin{array}{c}\text { Close } \\
\text { loop }\end{array}$ & $\begin{array}{c}\text { Open } \\
\text { loop }\end{array}$ \\
\hline Mean & 1026.74 & 1033.05 \\
\hline SD & 2.71 & 3.82 \\
\hline C.O.V. & 0.00264 & 0.00370 \\
\hline
\end{tabular}

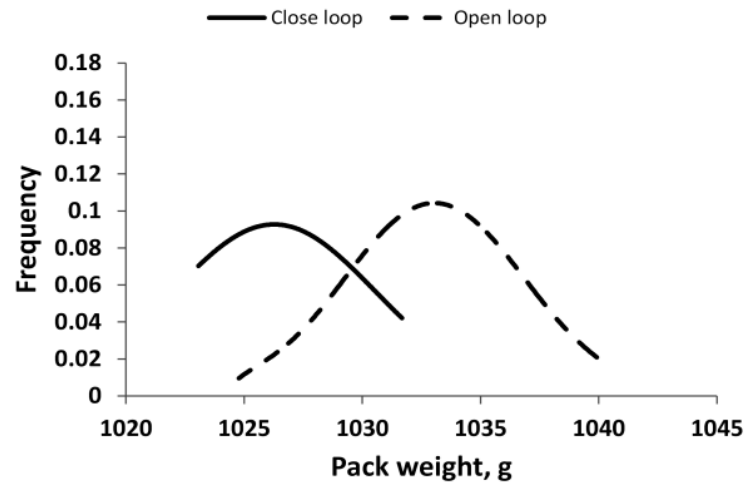

\section{LEMON}

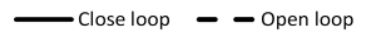

\begin{tabular}{|c|c|c|}
\hline \multirow{2}{*}{ Item } & \multicolumn{2}{|c|}{ Lemon } \\
\cline { 2 - 3 } & $\begin{array}{c}\text { Close } \\
\text { loop }\end{array}$ & $\begin{array}{c}\text { Open } \\
\text { loop }\end{array}$ \\
\hline Mean & 1007.88 & 1013.14 \\
\hline SD & 2.44 & 3.49 \\
\hline C.O.V. & 0.00242 & 0.00344 \\
\hline
\end{tabular}

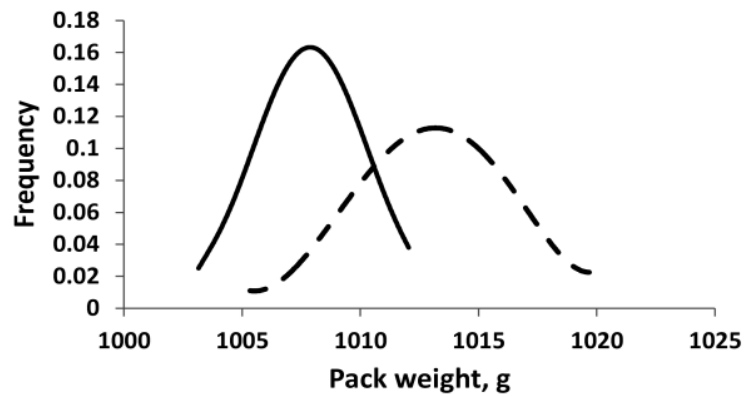

Figure 14. Normal distribution curves of pack weight precision under two different types of control systems for different types of fruits and vegetables, SD is standard deviation and C.O.V. is the coefficient of variation. 


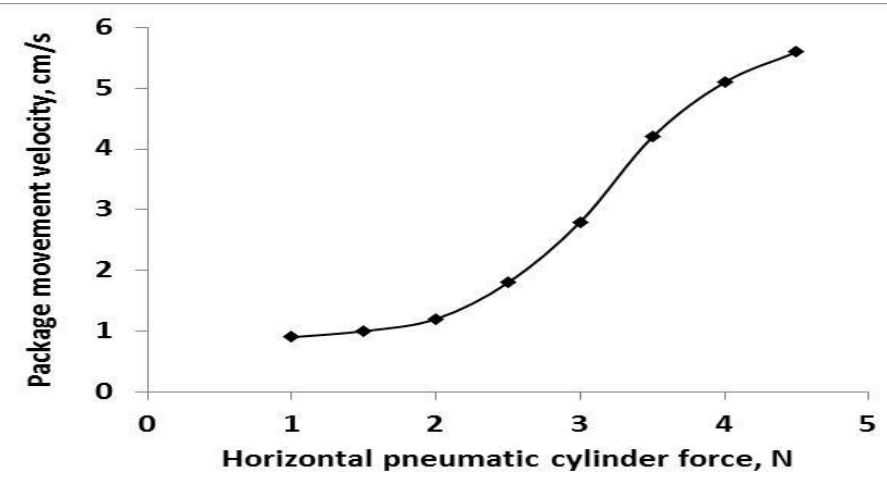

Figure 15. The effect of horizontal pneumatic cylinder pushing force on fruits package movement velocity from weighing unit to sealing unit

Table 6. The components costs of each innovative embedded control system

\begin{tabular}{|c|c|c|c|c|c|}
\hline \multicolumn{2}{|c|}{ First embedded system } & \multicolumn{2}{|c|}{ Second embedded system } & \multicolumn{2}{|c|}{ Third embedded system } \\
\hline Item & $\begin{array}{l}\text { Cost, } \\
\text { LE }\end{array}$ & Item & $\begin{array}{l}\text { Cost, } \\
\text { LE }\end{array}$ & Item & $\begin{array}{c}\text { Cost, } \\
\text { LE }\end{array}$ \\
\hline $\begin{array}{l}\text { Arduino-Uno (made } \\
\text { in Italy) }\end{array}$ & 400.00 & Timer NE555N & 2.50 & Timer NE555N & 2.50 \\
\hline $\begin{array}{l}\text { Arduino shield for } \\
\text { DC } \quad \text { motor } \\
\text { (Switching circuit) }\end{array}$ & 80.00 & $\begin{array}{c}\text { Three capacitors } \\
\text { of } 100 \mathrm{nF}\end{array}$ & 2.25 & $\begin{array}{l}\text { Quad XOR } \\
\text { Gate 4030 } \\
\text { (comparator) }\end{array}$ & 3.00 \\
\hline $\begin{array}{ll}\text { Infrared sensor } \\
\text { LED* }\end{array}$ & 1.5 & Resistor $470 \Omega$ & 0.05 & $\begin{array}{c}\text { Rotary Encoder } \\
*\end{array}$ & 40.00 \\
\hline Infrared receiver* & 7.5 & Resistor $150 \mathrm{~K} \Omega$ & 0.05 & $\begin{array}{l}\text { RC Low pass } \\
\text { filter* }\end{array}$ & 2.50 \\
\hline Load cell $5 \mathrm{Kg}^{*}$ & 110.00 & Resistor $1 \mathrm{~K} \Omega$ & 0.05 & $\begin{array}{c}\text { Three } \\
\text { capacitors of } \\
100 \mathrm{nF}\end{array}$ & 2.25 \\
\hline HX711* & 65.00 & Resistor $120 \Omega$ & 0.05 & Resistor $470 \Omega$ & 0.05 \\
\hline 4043 Tristate* & 15.00 & $\begin{array}{l}\text { Transistor } \\
\text { TIP31* }\end{array}$ & 12.00 & $\begin{array}{l}\text { Resistor } \\
150 \mathrm{~K} \Omega\end{array}$ & 0.05 \\
\hline $\begin{array}{l}\text { MOSFET } \\
\text { IRFZ44E* }\end{array}$ & 18.00 & $\begin{array}{l}\text { Variable resistor } \\
100 \mathrm{~K} \Omega\end{array}$ & 0.5 & Resistor $1 \mathrm{~K} \Omega$ & 0.05 \\
\hline Total & 697 & $\begin{array}{l}\text { Two Diodes of } \\
\text { 1N4148 }\end{array}$ & 1.00 & Resistor $120 \Omega$ & 0.05 \\
\hline \multirow{4}{*}{\multicolumn{2}{|c|}{$\begin{array}{l}* \text { These components are used for } \\
\text { any control system for data } \\
\text { acquiring and conditioning besides } \\
\text { the central processing units } \\
\text { (Arduino or PLC). Prices are }\end{array}$}} & $\begin{array}{l}\text { One Diode of } \\
\text { 1N4001 }\end{array}$ & 0.50 & $\begin{array}{l}\text { Transistor } \\
\text { TIP31* }\end{array}$ & 12.00 \\
\hline & & Total & 19.05 & $\begin{array}{l}\text { Variable } \\
\text { resistor } 100 \mathrm{~K} \Omega\end{array}$ & 0.5 \\
\hline & & & & $\begin{array}{l}\text { Two Diodes of } \\
1 \mathrm{~N} 4148\end{array}$ & 1.00 \\
\hline & & & & Total & 64.05 \\
\hline
\end{tabular}

updated on 01/01/2018. 
The prices of the other control systems as PLC varied from 5000 to 30000LE (Siemens, 2018a\&b and China, 2018) for each unit according to its quality and the manufacturer origin country China and Germany. If the electronic components used with any control system were excluded the first, second and third embedded system will cost 480, 7.05 and 21.55LE, respectively. In comparison with the application of PLC systems, the minimum cost can be obtained is above 2000LE per each function of the embedded system to be in total above 6000LE. However, the embedded systems created in the current investigation cost in total without any exclusion is 780LE.

\section{CONCLUSIONS}

Packaging is one of the most familiar techniques for food preservation and distribution contributions. This investigation is concerned about create a new alternative low-cost control system for packaging process using the modernist engineering techniques (phase locked loop technique integrated with pulse width modulation signal conditioning technique) for designing close loop control system for DC motor rotational speed consistency and using only the pulse width modulation technique for constructing the other type of control (open loop system). Series studies and arrangements among agricultural products, control circuits of open and close loop control systems and mechanical parts were carried out for appropriate synchronization. Physical properties of three different types of agricultural products were studied, two types of fruits lemon and plum and one type of vegetables tomato were selected for their spherical shapes. Morphological dimensions were determined for optimum packaging process. Lemon and plum have higher sphericity index of 94.4 and $92.8 \%$, respectively than tomatoes of $76.27 \%$. Due to higher sphericity index, lemon and plum are rolling easier on flat surfaces than tomatoes. Nodded belt conveyer was chosen for its higher friction coefficient of $12 \pm 0.72^{\circ}, 13 \pm 0.94^{\circ}$ and $18 \pm 2.15^{\circ}$ with lemon, plum and tomatoes, respectively. Apparent volume affects significantly weighing precision. Tomatoes have lowest pack weight precision of $1029.6 \pm 3.2 \mathrm{~g}$ due to its higher apparent volume of $790 \pm 23.12 \mathrm{~cm}^{3}$ and lower sphericity index and aspect ratio of 76.27 and $63.3 \%$, respectively. However, on the 
other hand, lemon has the highest pack weight precision of $1007.38 \pm 3.55 \mathrm{~g}$. The packaging prototype is aimed to pack the same weight (one kilogram) of different agricultural products and envelop them in a high density polyethylene plate and covered with plastic sheets of polymer. Ohmic heating coil is used for polymer sealing after weighing and enveloping processes. The transportation from the hopper to weighing and to sealing units is done by two different operations of mechanical transmissions by: (1) conveyor belt and (2) pneumatic cylinder systems. Two horizontal and vertical pneumatic cylinders were used for pushing and sliding the packaging plate after filling from the weighing unit to be enveloped in plastic sheet to be in the sealing unit and other vertical pneumatic cylinder used to press the Ohmic heating coil on the packaging material for sealing operation. The optimum applied pressure by the vertical pneumatic cylinder was at $4 \mathrm{bar}$ and coil temperature of $54^{\circ} \mathrm{C}$ for optimum package welding without any faults within time of $4.33 \mathrm{~s}$. Three innovative embedded control systems were designed and investigated virtually by a software package of Proteus design suite 8 using open sources of hardware and software. The first embedded system was designed to control the operations of weighing and sealing. The two other embedded systems were for two different types of control systems (open and close loop control systems). Close loop system retains the rotational speed of DC motor constant. When DC driver motor is operated under different full and no-load conditions, the electrical current will increase from 0.45 to $1.01 \mathrm{~A}, 0.32$ to $0.48 \mathrm{~A}, 0.22$ to $0.34 \mathrm{~A}$ and 0.15 to $0.3 \mathrm{~A}$ for different levels of reference signal potentials of 100 , 75, 50 and 25\%, respectively. However, with the control open loop systems, the rotational speed of DC driver motor varies under full and noload conditions. The close loop control system performs higher operation of pack weighing precision and lower coefficient of variation of 0.00315 , 0.00264 and 0.00242 of tomatoes, plum and lemon packs, respectively. However, the open loop control system has lower pack weighing precision and higher coefficient of variation of $0.00510,0.00370$ and 0.00344 , respectively. Finally it can conclude that the close loop control system is most suitable control (third embedded system) for fruits and vegetable weighing automation working with the first embedded system 
used for pack transmissions and sealing. The overall control system costs were of $761.05 \mathrm{LE}$ in against of 5000 to 30000LE of other control systems.

\section{REFERENCES}

Algitta, A. A., S. Mustafa, F. Ibrahim, N. Abdalruof and M. Yousef. 2015. Automated packaging machine using PLC. International Journal of Innovative Science, Engineering \& Technology: 2(5): 282-288.

China, 2018. http://www.made-in-china.com/products-search/hot-chinaproducts/PLC.html, visited on 01/01/2018.

Durfee, W. 2011. Arduino microcontroller guide, University of Minnesota, ver. Oct. 2011, Available on www.me.umn.edu/courses/me2011/arduino/

Evans, B. 2011. Beginning Arduino programming: Writing code for the most popular microcontroller board in the world. Friend soft Apress, ISBN-13 (electronic): 978-1-4302-3778-5, P. 271.

Fey, J. J. H. 2000. Design of a fruit juice blending and packaging plant. Eindhoven: Technische Universiteit, Eindhoven.

Future, 2018. https://store.fut-electronics.com/, visited on 01/01/2018.

Henery, J. R. 2012. Packaging machinery handbook: The complete guide to automated packaging machinery, including packaging line design. Createspace Independent Pub, P. 366.

Kapoor, R.; Kulkarni, P.; Jenkins, N.; Krebs, M.; Blevins, B. B. 2006. Technology Roadmap Energy Efficiency in California's Food Industry. In California Energy Commission Public Interest Energy Research Program No. CEC-500-2006-073; University of California: Davis, CA, USA.

Lingappa, M. S., V. Bongale and Sreerajendra. 2014. PLC Controlled low cost automatic packing machine. International Journal of Advanced Mechanical Engineering, 4(7): 803-811.

Mahalik, N. P. 2009. Processing and Packaging Automation Systems: A Review. Special Issue on Advances in Food Automation, Sensing and instrumentation for food quality and safe, 3: 12-25. 
Mahalik, N. P. 2014. Advances in Packaging Methods, Processes and Systems, challenges, 5, PP. 374-389.

Mohsenin, N. N. 1978. Physical properties of plant and animal materials, Gorden and Breach Science Publisher, New York, USA.

RAM, 2018. http://ram-e-shop.com/oscmax/catalog/, visited on $01 / 01 / 2018$.

Razavi, S. M. A. and M. B. Parvar. 2007. Some Physical and Mechanical Properties of Kiwifruit. International Journal of Food Engineering, 3(6): 1-14.

Siemens, 2018a. http://www.isgautomation.com/siemens-simatic-s7-300plc-6es7.html, visited on 01/01/2018.

Siemens, 2018b. http://www.isgautomation.com/siemens-simatic-s7-200plc-6es7.html, visited on 01/01/2018.

$$
\text { الملخص العربي }
$$

نموذج أولي آلي مبتكر منخفض التكلفة لتعبئة وتغليف الفاكهة والخضر التربي

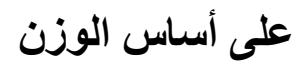

سعيد الثحات عبدالله * و و وائل محمد المسيري*

تعتبر عملية التعبئة والتغليف هي واحدة من التقنيات الأكثر شيوعاً وإسهاماً لحفظ الأغذية

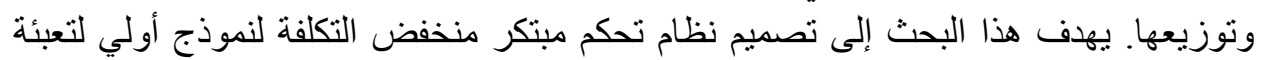
وتغليف منتجات الفاكهة والخضر باستخدام أحدث تقنيات التحكم الهندسية (تقنية حلقة الطور pulse width و المقطوعة phase locked loop modulation



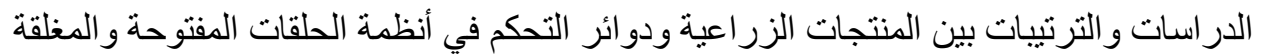
و الأجزاء الميكانيكية من أجل التز امن المناسب.

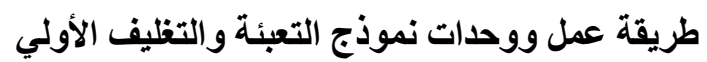

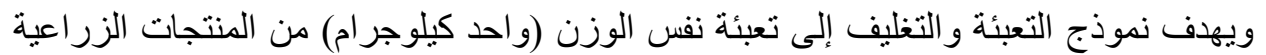

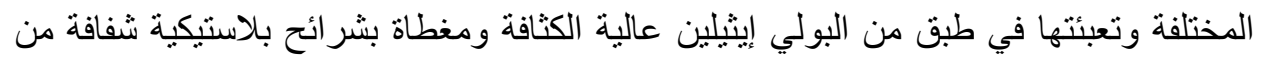

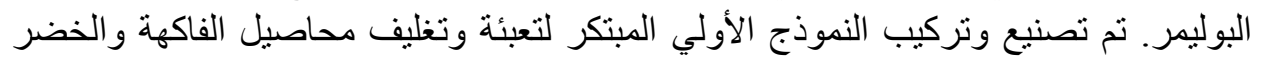

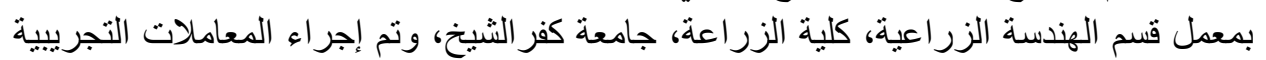



* أستاذ هندة التصنيع الزراعي المساعد ـ قسم الهندسة الزراعية ـ كلية الزراعة ـ جامعة كفر الثيخ 
وحدتي نقل الثمار والعبوات

يتم النقل من القادوس إلى وحدات الوزن ثم اللحام من خلال نظامي نقل مختلفين من أنظمة النقل الميكانيكي، النقل بالسير وبالهو اء المضغوط. تم إستخدام إثنين من الإسطوانات الهوائية الأفقية و الر أسية. الإسطوانة الهو ائية الأفقية مثبتة بأسفل السير الناقل وتستخدم حين إنتهاء عملية الملئ

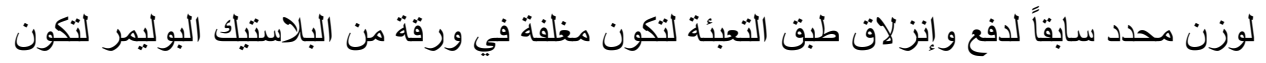

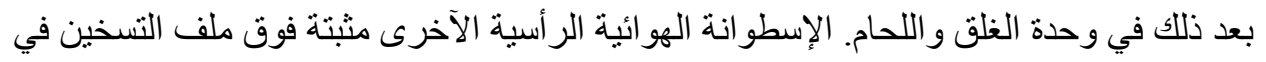
وحدة الغلق و اللحام. وتستخدم هذه الإسطوانة لدفع ملف التسخين ليضغط على مواد التعبئة و التخليف ليقوم بعملية اللحام.

وحدة الوزن ونان

تتكون وحدة الوزن من صفيحة معدنية مثبتة على خلية حمل سعة وزن خمسة كيلو جر ام مثبت فوقها لمبة إنبعاث أشعة تحت حمر اء و التي تقوم بوظيفة إبتداء تشغيل موتور إدارة السير الناقل

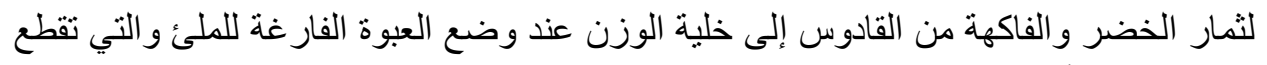

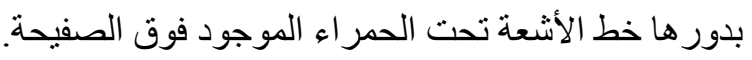
وحدة ققل وغلق العبوة تم إستخدام ملفات التسخين للحام وقفل الثرائح البوليمر بعد عمليات الوزن و التغليف، و التي تكون مثبتة أسفل الأسطو انة.

للحصول على نظام تحكم أمثل فقد أجريت هذه الدراسة على عدة محاور:

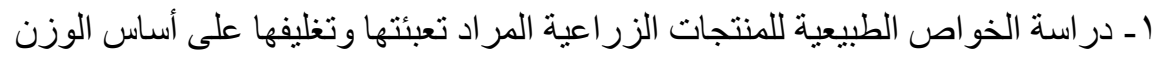

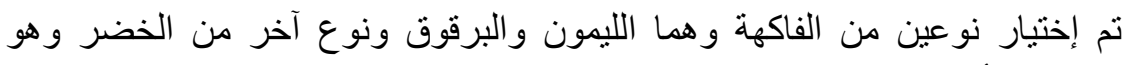
الطماطم لأشكالها الكروية.

من أهم النتائج المتحصل عليها من دراسة الخواص الطبه الطيعية أن:

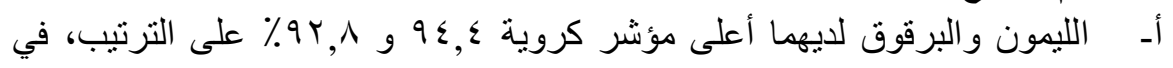

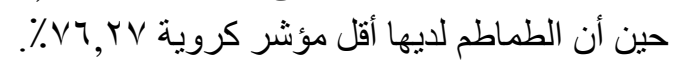

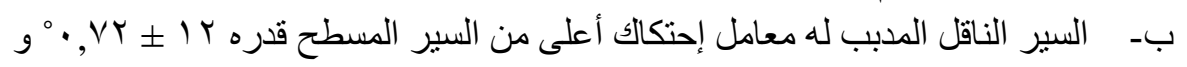

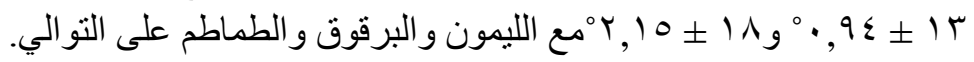

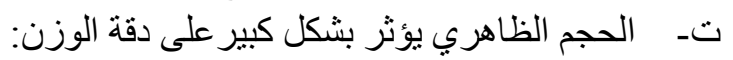

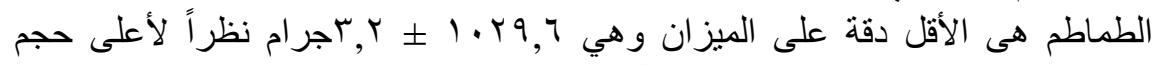

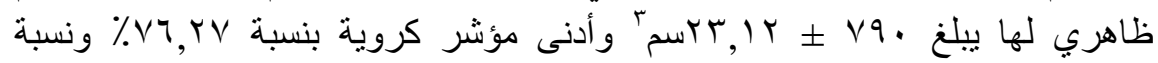

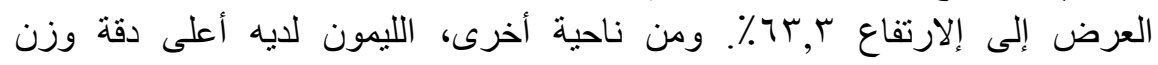

$$
\text { ل }
$$

r- تصميم وتحليل أداء الثلاثة نظم التحكم المدمجة باستخدام برنامج التصميم الإفتراضي بروتوس

تم إستخدام الأجهزة ذات المصادر المفتوحة open sources (محكمات الأردوينو

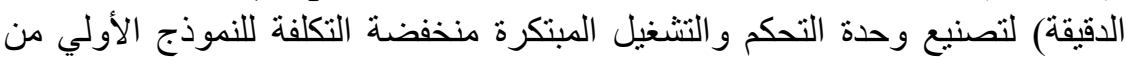
خلال ثصميم ثلاثة نظم تحكم مدمجة: 
أـ الأول لجلب البيانات من خلية الحمل load cell للوقوف على وزن العبوة لحظة

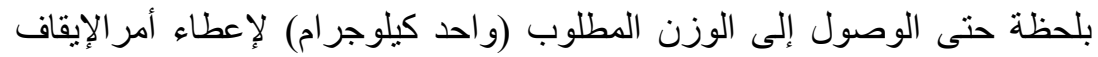

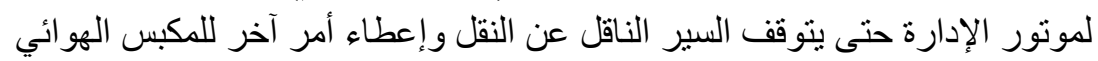

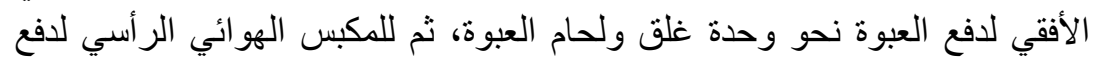

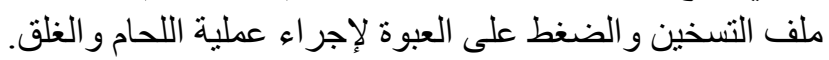

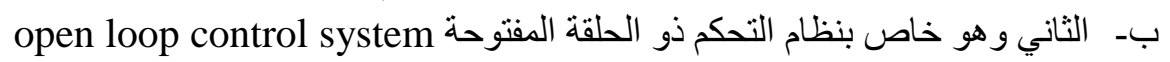

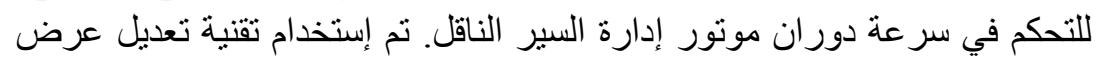
النبضة pulse width modulation مباشرة لتنظيم سر عة موتور السير الناقل في دور الني نظام التحكم ذو الحلقة المفتوحة بناءاً على تعديل قيمة المقاومة يدوياً لمقاومة متغيرة التهرة

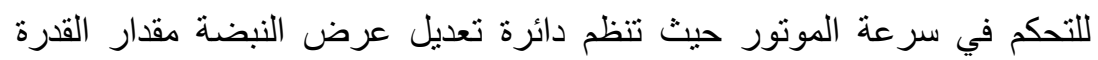
الكهربائية المضافة إلى دو ائر الحلقة المفتوحة. تـ الثالث وهو خاص بنظام التحكم ذو الحلقة المغلقة close loop control system للتحكم في سرعة دوان موتور إدارة السير الناقل بحيث تضمن ثبوتية سر عة دوران

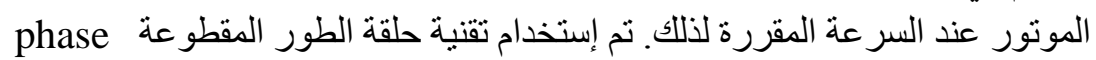
pulse width و المتكاملة مع تقنية تعديل عرض النبضة locked loop modulation

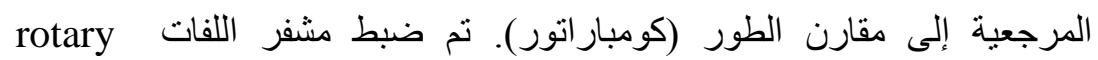
encoder

للحصول على النسبة المناسبة لعمل المقارن XOR Comparator.

rـ المقارنة بين نظامي التحكم ذو الحلقة المفتوحة open loop control system و الحلقة المغلقة close loop control system للتحكم في سر عة دوران موتور إدارة السير الناقل فئل

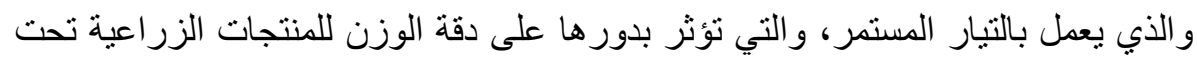

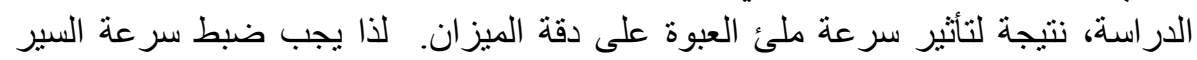

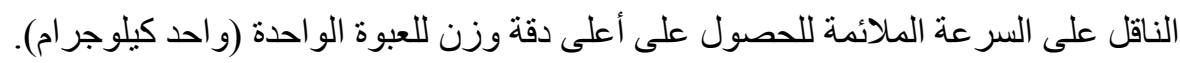

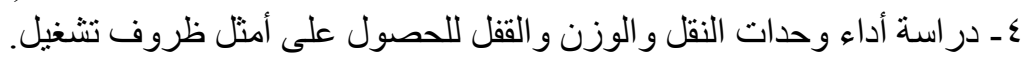

وحدة ققل وغلق العبوة

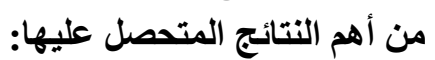

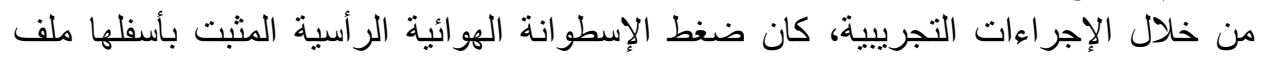

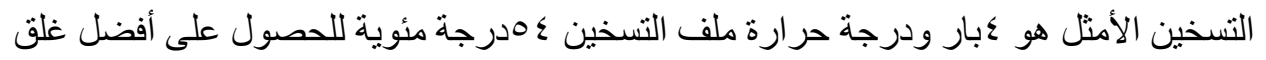

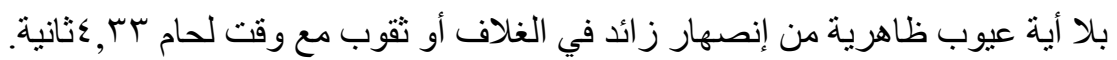

وحدة النقل

سرعة دوران موتور إدارة السير الناقل

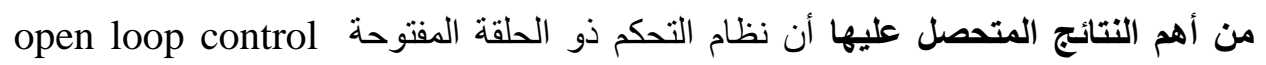
system

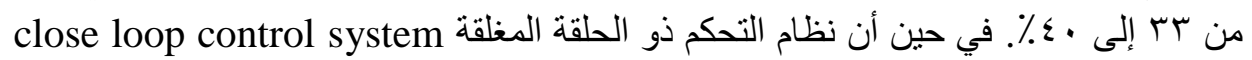


يقي سرعة دوران مونور السير الناقل ثابتة، ولكنه يستهلك المزيد من الطاقة الكهربائية من ـ إلى 100\%

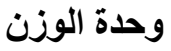

تم عمل دراسة مقارنة بين نظامي التحكم ذو الحلقة المفتوحة والحلقة المغلقة لمونور إدارة السير

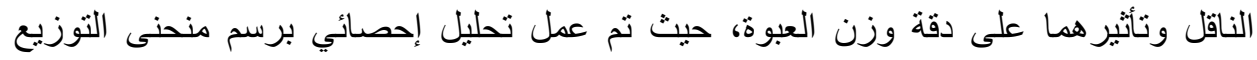

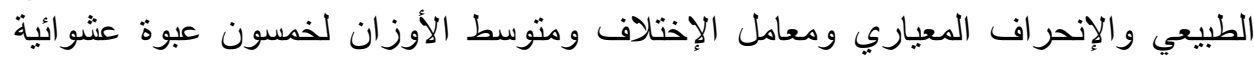



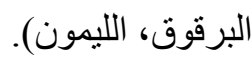
من أهم النتائج المتحصل النعل عليها أن:

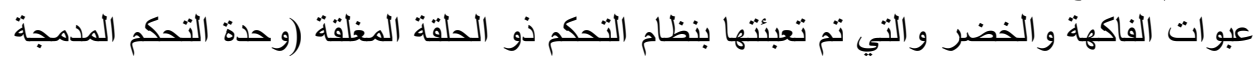

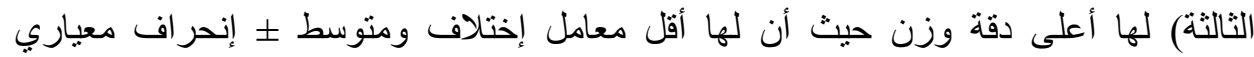

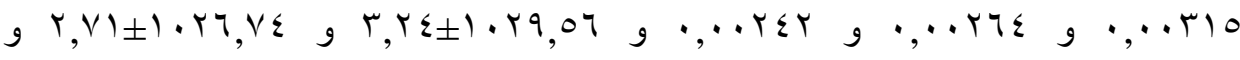
وحدا



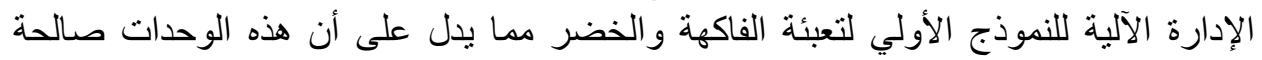

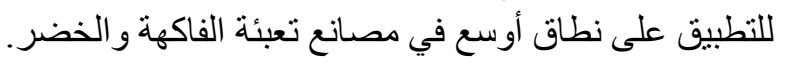

المساهمة الإقتصادية لوحدة التحكم المدمجة لوحدات تعبئة وتظليف الفاكهة والخضر على

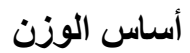
تم عمل در اسة مقارنة بين تكاليف شر اء وحدات تحكم جاهزة الصنع من الخارج ووحدات التهر التحكم

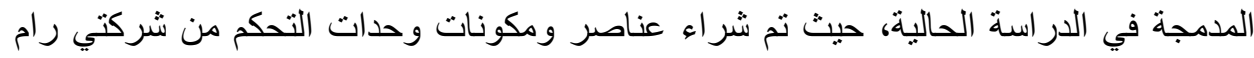

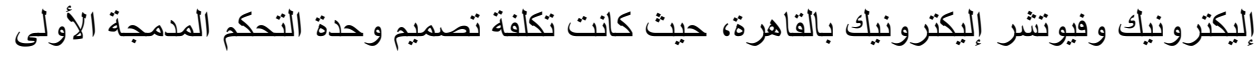

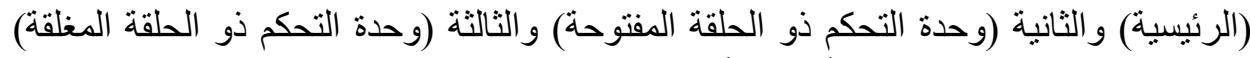

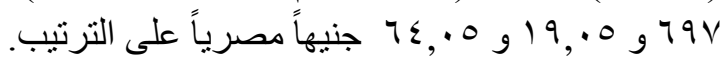
يحتاج هذا العمل إلى المزيد من الإجراءات البحثية لاستكمال إيتكار مواد تعبئة وتغليف ذكية

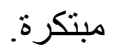

